\title{
FACTORS INFLUENCING CONSUMERS' PURCHASING DECISIONS TOWARDS POMELO FRUITS (Citrus grandis) IN JOHOR, MALAYSIA
}

\author{
Siti Fatimah Binti Misman*), Nurul Aisyah Binti Mohd Suhaimi*), Afnani Binti Alwi ${ }^{*}$
}

${ }^{*}$ Faculty of Bioresources and Food Industry, Universiti Sultan Zainal Abidin, Malaysia Besut Campus, 22200 Besut, Terengganu Darul Iman, Malaysia

\begin{abstract}
Pomelo (Citrus grandis or Citrus maxima) is a tropical fruit from Rutaceae family has grown in Malaysia. These natural, non-hybrid citrus fruits originated from Southeast Asia and widely grown in Indonesia, China and Thailand (Morton, 1987; Scora, 1975). Commonly known as Limau Kepala Besar, Limau Bali (pomelo), Limau Tambun and Limau Besar Ledang, this fruit have four famous varieties such as Varieties PO51 (Shanting), Varieties PO52 (Tambun), Varieties PO55 (Limau Besar, Ledang) and Varieties PO56 (Melomas Variety) which can be found in the local and global markets. The aim of this research is to study the characteristics behind every purchasing decision through personal, socio-cultural and psychological factors of consumer. Data were collected using online questionnaire which a total of 100 forms were distributed around Johor, Malaysia. The data were analyzed to identify the relationship between respondent profiles and identify the most influential factors that show the relationship associations with consumer purchasing decisions on pomelo fruits. The results showed that personal, socio-cultural and psychological factors have influenced consumers' decision-making process when buying the pomelo fruits.
\end{abstract}

Keywords: consumer buying behaviour, pomelo, purchasing decisions

Abstrak: Pomelo (Citrus grandis atau Citrus maxima) adalah buah tropis dari famili Rutaceae yang tumbuh di Malaysia. Buah jeruk non-hibrida alami ini berasal dari Asia Tenggara dan banyak ditanam di Indonesia, Cina dan Thailand (Morton, 1987; Scora, 1975). Umumnya dikenal sebagai Jeruk Nipis Kepala Besar, Jeruk Bali (Pomelo), Jeruk nipis Tambun dan Jeruk nipis Ledang, buah ini memiliki empat varietas terkenal seperti Varietas PO51 (Shanting), Varietas PO52 (Tambun), Varietas PO55 (Limau Besar, Ledang) dan Varietas PO56 (Varieta Melomas) yang dapat ditemukan di pasar lokal dan global. Penelitian ini bertujuan mempelajari karakteristik di balik setiap keputusan pembelian melaluifaktor pribadi, sosial budaya dan psikologis konsumen. Pengumpulan data dilakukan dengan menggunakan kuesioner online sebanyak 100 formulir yang disebar di sekitar Johor, Malaysia. Data dianalisis untuk mengidentifikasi hubungan antara profil responden dan mengidentifikasi faktor-faktor yang paling berpengaruh yang menunjukkan hubungan hubungan dengan keputusan pembelian konsumen pada buah jeruk bali. Hasil penelitian menunjukkan bahwa faktor personal, sosial budaya dan psikologis mempengaruhi proses pengambilan keputusan konsumen dalam membeli jeruk bali.

Kata kunci: perilaku pembelian konsumen,jeruk bali, keputusan pembelian

${ }^{1}$ Corresponding author:

Email: nurulaisyah@unisza.edu.my 


\section{INTRODUCTION}

The largest citrss fruit from the Rutaceae family, pomelo (Citrus grandis or Citrus maxima) (Nathan \& Wong, 1987) is a tropical fruit suitable for growing in Malaysia. It is believed to be from Southeast Asia and is widely grown in Indonesia, China and Thailand (Morton, 1987; Scora, 1975). According to the Department of Agriculture's Statistics Report 2019 (DOA's Statistic Report, 2019) approximately 1,056 hectares of pomelo are planted in Malaysia with a production of 15,740 metric tonnes. About $70-80 \%$ of the total cultivated varieties in Malaysia, Pomelo Varieties PO51 (Shanting), Varieties PO52 (Tambun) and Varieties PO55 (Limau Besar Ledang) are among the pomelo varieties that have long been known to grow. However, the pomelo variety PO56 (Melomas Variety) has now become an option for commercialization as it is believed to have a very tasty and sweet taste compared to other varieties. The variety registered in 2002 originated in Johor and has now been introduced as the fourth choice of pomelo varieties suitable for commercialization internationally.

Fruits and vegetables consumptions are a cheap way to meet the nutritional requirements. Futhermore, the fruits consumption behaviour is much better than snacks or dessert as an appetizer. Consumer behaviour is a field that has been universally studied. It is absolutely difficult to understand because it is connected closely to the human mind. However, predicting how past purchasing decisions can estimate human behaviour in buying situations (Lautiainen, 2015; Wright, 2006). Fresh fruits and vegetables are an integral part of consumers food expenditure. Every customer wishes to get fresh vegetables for good value for money on the market and expects good quality, free, hygienic and safe products from pests and diseases for an affordable price (Kanchan \& Neeraj, 2018). Consumers would also prefer healthy and good quality vegetables and fruits. However, yet the decision-making process is complex, and the importance of motives (marketing activities, ecological issues and others) and barriers (price, awareness and others) may affect the buying behaviour of consumers (Kanchan \& Neeraj, 2018; Padel \& Foster, 2005). Nevertheless, as far as fresh vegetables and fruit are concerned, non-price considerations such as product quality, shelf life, place of purchase, place of origin of vegetables, nutritional values, safety knowledge and others play an important role in deciding the purchase decision (Kanchan \& Neeraj, 2018; Chikkamath et al. 2012).

In Malaysia, pomelo plant is widely grown in Kedah, Johor, Perak and Melaka. In recent year, the demand for pomelo fruit is increasing (Ismail, 2019). However, the level of pomelo fruit production seems to be declining because of hot weather (Ismail, 2021). Thus, pomelo farmers have to limit their export to neighbor countries in order to meet the local demand.

The purchase of fresh fruit such as pomelo comes almost spontaneously and requires little scanning for information. Some features can be derived from cultural, social, personal or psychological factors behind any purchasing decision. Each of these variables has parameters that could be used in marketing. These variables can be used so strategically by marketers that consumers may not even be understood or noticed. Knowing the various elements that trigger a customer's buying activity can help a business manager use appropriate sales techniques. Thus, given a snapshot of understanding consumer preferences on how the pomelo fruits purchased has been illustrated and what considerations are taken to avoid facing a problem while purchasing causes the farmers not to offer a reasonable price with a good quality produced in the future.

The general objective of this study is to identify the factors influencing consumers' purchasing decisions towards pomelo fruits (Citrus grandis) in Johor, Malaysia. The specific objectives were to identify consumer behavior factors that influence consumer decision-making when purchasing pomelo fruits and to identify the relationship between the most influential independent factors and the consumers' purchasing decisions on pomelo fruits.

\section{METHODS}

The study was conducted in 10 districts in Johor which are Johor Bahru, Batu Pahat, Kluang, Kulai, Muar, Kota Tinggi, Segamat, Pontian, Tangkak and Mersing. The state of Johor was chosen because of their production of pomelo fruit. In addition, Johor was selected by the Department of Agriculture Malaysia as one of the producers for pomelo fruit as it is seen to have a high potential for commercialization, especially the Melomas variety (PO56). 
Due to the current situation faced by global including Malaysia, the outbreak of a pandemic disease known as Coronavirus (Covid-19), the data were collected using designated questionnaires and were distributed in the form of a Google document link. One hundred respondents were chosen using the convenience sampling. The questionnaire was divided into three sections.

The data were analysed using Statistical Package for Social Science (SPSS) software version 25 to explore potential outcomes that overview customer knowledge, beliefs, perceptions of pomelo fruits and factors that influence consumer buying behaviours. For the data analysis, the reliability analysis, the descriptive analysis of frequencies and the contingency tables or crosstabulation analysis with chi-squares test were employed. Descriptive analysis was used to describe the methods of organizing, summarizing and presenting data in an informative way on the sociodemographic profile of the respondents in terms of frequencies and percentages. The reliability analysis describes the degree to which it is bias-free (error-free) and thus ensures accurate measurement over time and over the different objects in the instrument. In other words, the reliability of a measure is an indicator of the stability and precision with which the concept is calculated by the instrument and helps to determine a measure's "goodness." Thus, to analyse the internal consistency, the reliability analysis utilises Cronbach's alpha. In most cases, the alpha of Cronbach can be considered a perfectly index of the reliability of interitem consistency (Uma \& Roger, 2016). According to Glen et al. (2014), Cronbach's alpha, $\alpha$ or known as coefficient alpha was used to tests to see if multiplequestion Likert-scale surveys are reliable

Cronbach's Alpha tests the internal consistency between the items in a scale. Internal means that we were looking at how respondents share their response to all the items. So, if respondents were said responding above from the scale such as neutral, agree and strongly agree, therefore, we would expect them to be responding that way for each item in the scale. We do not want to see that they are responding like strongly agree for some items and then strongly disagree for other items because it is shown that it is inconsistent. Internal consistency can vary between zero and one for Cronbach's Alpha, calculated with correlations between all pairs of items, although there are often abnormal negative values (Ursachi et al. 2015). Therefore, the positively questions in the scale must not mixed with the negatively questions before analysed these tests or otherwise we will get negatively of $\alpha$-values. So that, if necessary, reverse the code variables of one of the positive or negative questions. Generally, $\alpha$-values of Cronbach's Alpha acceptable rule is between 0.6-0.7 denotes a reasonable reliability level and greater than 0.8 denotes a very good level. However, values above 0.95 are not typically good as it might be an indicator of redundancy (Hulin et al. 2001; Ursachi et al. 2015)

The instruments of measurement scales used were nominal scales, ordinal scales and Likert scales data recorded at the nominal level of measurement represented as labels or names. There is no particular order to the labels. The labels or names can only be classified and counted. For instance, with respect to gender, respondents can be grouped into two categories: the code number 1 to all-male respondents and number 2 to all female respondents. Meanwhile, the ordinal data labelled based on a relative ranking or rating of items based on a defined attribute or qualitative variables. The variables based on this level of measurement were only ranked and or counted. For example, respondents were asked about their level of educations. Likert scales was one of the many options used to classify consumers in which means it is a scale designed to examine how strongly respondents shared their responses according to the questionnaires such as "I enjoy eating pomelo fruits" on a five-point scale represented: $1=$ Strongly disagree until $5=$ Strongly agree.

The weighted mean was used to calculate the sample mean of the random variables related to each other to be tested and for better understanding for further analysis to answer the objectives. It was a convenient way to compute the arithmetic mean when several observations of the same variables or values (Lind et al. 2018). For example, to find the mean of independent variables behind these three factors, each of these factors had five Likert-scale questions of personal factors, four Likert-scale questions of socio-cultural factors, and three Likert-scale questions of psychological factors. This is because the exact criteria for crosstabulation analysis were categorical data required when either or both were nominal and ordinal measurement scales. Therefore, the final output results were not violated its assumptions, and we got the new output variables labelled as nominal and ordinal scale. This analysis used to analyze three factors of independent variables (Table 1). Thus, the results stated that the socio-cultural 
factors had the highest $\alpha$-values $=0.729$, which was nearing to 1 , followed by the personal factors had $\alpha$-values $=0.624$. The lowest goes to the psychological factors that had $\alpha$-values $=0.287$ whereas the final results for overall independent variables was $\alpha$-values $=$ 0.786 . Since the total showed nearing to 1 , it is reliable enough to be used for crosstabulation analysis with chisquare tests. Thus, when we ran the crosstabulations analysis, we got the resulting data easily interpreted and read off.

Table 1. Reliability Statistics

\begin{tabular}{lccc}
\hline \multicolumn{1}{c}{$\begin{array}{c}\text { Independent } \\
\text { Variables }\end{array}$} & $\begin{array}{c}\text { Cronbach's } \\
\text { Alpha }\end{array}$ & $\begin{array}{c}\text { Cronbach's } \\
\text { Alpha Based } \\
\text { on } \\
\text { Standardized } \\
\text { Items }\end{array}$ & $\begin{array}{c}\mathrm{N} \text { of } \\
\text { items }\end{array}$ \\
\hline $\begin{array}{l}\text { Personal Factors } \\
\text { Socio-cultural }\end{array}$ & 0.624 & 0.614 & 5 \\
Factors & 0.729 & 0.739 & 4 \\
$\begin{array}{l}\text { Psychological } \\
\text { Factors }\end{array}$ & 0.287 & 0.315 & 3 \\
Total & 0.786 & 0.788 & 12 \\
\hline
\end{tabular}

\section{RESULTS}

The findings show that the consumers' demographic profile, beliefs, perceptions toward pomelo fruits, and factors that influenced their purchasing decisions when buying this fruit.

Table 2 shows respondents' demographic profile in Johor regarding the percentage of respondents' involvement, which represents the number of respondents who participated in the survey questionnaire. In the gender group, 33\% represented the male gender. $33 \%$ also show consumers' involvement from rural areas and $67 \%$ representing the female gender, indicating consumers' involvement from rural areas.

The majority of consumers, which represent $61 \%$ of the respondents, are in the age group of 21 - 30 years, and the minority of consumers, which consists of $3 \%$, are in the age group of more than 51 years old. Meanwhile, within the age group with similar percentage are between $31-40$ years old and $41-50$ years old. It was observed that a minority of 11 respondents (11\%) only has experience in engaging to answer online questionnaires. Alternatively, it is safe to say that they are only willing to share their perceptions with others as their personal information will be automatically anonymous. Observations of data in terms of age are needed to which age group are more interested in consuming pomelo fruit. Significant variations in purchasing conduct when contrasting adolescents and middle-aged to older adults (Solomon et al. 2008). Youth tend to be much more familiar with using the Internet and comfortable researching knowledge about products and services through the Internet (Monsuwee et al. 2004).

The percentages of respondents involved are Malays (84\%), Chinese (9\%), Indians (6\%) and other races such as Aborigines or native people (Orang Asli) (1\%). Therefore, the results showed that the highest percentage was conquered by the races, representing the majority group in Johor. Observing the respondents' educational level is important to justify the level of consumer knowledge and awareness about the importance of fruit consumption in an individual's healthy lifestyle. Around $88 \%$ of the respondents obtained educational level up to tertiary levels such as STPM, Vocational, Matriculation, Diploma, Bachelor's Degree, Master, and others, while $12 \%$ of respondents had secondary education status. Besides, personality changes as a person evolved and changed the environment of their surrounding throughout their life. Customers tend to develop a set of beliefs about a product based on their faith, knowledge or experience (Kotler and Armstrong, 2014).

From the data, $72 \%$ of the respondents are still single, $25 \%$ are married, and $3 \%$ stated as others. As for family dependents, $48 \%$ of the respondents do not have any family dependents. A total of $29 \%$ of the respondent answered that there are family members of 1-3 people under their care. They were followed by $20 \%$ of the respondent that needs to support family members between 4-6 people. In the meantime, between 7-9 dependent family members are accounted for $1 \%$ of the respondents and supporting more than ten family members for $1 \%$ of the respondents. From the results, $45 \%$ of respondents prefer to buy fruit once a week, $29 \%$ of the respondents prefer to buy once in every two weeks while $16 \%$ of the respondents procure fruits once a month, and $10 \%$ of respondents prefer to buy fruits once in every two months. As stated by Uusitalo et al. (2001), each stage brings different demands from the consumer. Stages greatly influence the quantity and types of products purchased at the grocery store in the family life cycle. 
Table 2. Respondents' demographic profile

\begin{tabular}{|c|c|c|}
\hline Variables & $\begin{array}{l}\text { Frequency } \\
(\mathrm{n}=100)\end{array}$ & $\begin{array}{c}\text { Percentages } \\
(\%)\end{array}$ \\
\hline \multicolumn{3}{|l|}{ Gender } \\
\hline Male & 33 & 33 \\
\hline Female & 67 & 67 \\
\hline Total & 100 & 100 \\
\hline \multicolumn{3}{|l|}{ Age } \\
\hline$<20$ years old & 14 & 14 \\
\hline 21 years old -30 years old & 61 & 61 \\
\hline 31 years old - 40 years old & 11 & 11 \\
\hline 41 years old - 50 years old & 11 & 11 \\
\hline$>51$ years old \& above & 3 & 3 \\
\hline Total & 100 & 100 \\
\hline \multicolumn{3}{|l|}{ Race } \\
\hline Malays & 84 & 84 \\
\hline Chinese & 9 & 9 \\
\hline Indians & 6 & 6 \\
\hline Others & 1 & 1 \\
\hline Total & 100 & 100 \\
\hline \multicolumn{3}{|l|}{ Living Area } \\
\hline Urban & 67 & 67 \\
\hline Rural & 33 & 33 \\
\hline Total & 100 & 100 \\
\hline \multicolumn{3}{|l|}{ Education Level } \\
\hline No education & 0 & 0 \\
\hline Primary School & 0 & 0 \\
\hline Secondary School & 12 & 12 \\
\hline $\begin{array}{l}\text { > STPM, Vocational, } \\
\text { Matriculation, Diploma, } \\
\text { etc. }\end{array}$ & 43 & 43 \\
\hline $\begin{array}{l}\text { > Bachelor's Degree, } \\
\text { Master, etc. }\end{array}$ & 45 & 45 \\
\hline Total & 100 & 100 \\
\hline \multicolumn{3}{|l|}{ Marital Status } \\
\hline Single & 72 & 72 \\
\hline Married & 25 & 25 \\
\hline Others & 3 & 3 \\
\hline Total & 100 & 100 \\
\hline
\end{tabular}

Consumers are divided into six working-level classes to assess the employment history of the respondents concerning this survey. Twenty-nine respondents are working in the private sector ( $29 \%), 26$ respondents are students (26\%), 22 government sectors (22\%), 14 who is self-employed (14\%), eight respondents are unemployed $(8 \%)$, and one respondent $(1 \%)$ is a retire. In terms of consumer monthly income, most of the consumers had a monthly income below RM 1000 , representing $37 \%$ of the respondents, followed

\begin{tabular}{|c|c|c|}
\hline Variables & $\begin{array}{c}\text { Frequency } \\
(\mathrm{n}=100)\end{array}$ & $\begin{array}{c}\text { Percentages } \\
(\%)\end{array}$ \\
\hline \multicolumn{3}{|l|}{ Working Level } \\
\hline Unemployed & 8 & 8 \\
\hline Self-employed & 14 & 14 \\
\hline Private & 29 & 29 \\
\hline Government & 22 & 22 \\
\hline Still studying & 26 & 26 \\
\hline Retirement & 1 & 1 \\
\hline Total & 100 & 100 \\
\hline \multicolumn{3}{|l|}{ Monthly Income } \\
\hline$<\mathrm{RM} 1,000$ & 37 & 37 \\
\hline RM 1, $100-$ RM 2, 000 & 32 & 32 \\
\hline RM 2, $100-$ RM 3. 000 & 14 & 14 \\
\hline RM 3, $100-$ RM 4, 000 & 5 & 5 \\
\hline$>\mathrm{RM} 4,100$ & 12 & 12 \\
\hline Total & 100 & 100 \\
\hline \multicolumn{3}{|l|}{ Family Dependent } \\
\hline None & 48 & 48 \\
\hline $1-3$ persons & 29 & 29 \\
\hline $4-6$ persons & 20 & 20 \\
\hline $7-9$ persons & 2 & 2 \\
\hline$>10$ persons & 1 & 1 \\
\hline Total & 100 & 100 \\
\hline \multicolumn{3}{|c|}{ Fruit Shopping Frequency } \\
\hline Once a week & 45 & 45 \\
\hline Once every 2 weeks & 29 & 29 \\
\hline Once a month & 16 & 16 \\
\hline Once every 2 months & 10 & 10 \\
\hline Total & 100 & 100 \\
\hline
\end{tabular}

by monthly income groups between RM1100 - RM 2000, representing $32 \%$. Meanwhile, $14 \%$ represents respondents who had monthly income between RM 2100 - RM 3000 are $14 \%$, and $12 \%$ is salaried within the range of more than RM 4000. However, within the monthly income of RM 3100 - RM 4000, there are only 5\% respondents. Solomon et al. (2004) stated that generally, they interact with each other and share the same values and ideas. The level of income affects what the consumer can afford and the prospect of money. 
Table 3 shows crosstabulation analysis results of consumer's purchasing decisions based on gender. Some statements have been taken randomly to address the questions in Objective 1. The researcher intends to identify consumers' decision making in the early purchasing process on finding knowledge and performing alternative tests to learn more about pomelo fruits. The findings show that male consumers are inclined to agree that they feel more practical to get information related to pomelo fruit by researching on the Internet such as is that any promotional offers were happening?, where else they can get buy these fruits faster? or is that this seller can provide good quality if they want to buy it?, and also reviewing feedback from other consumers and marketing activities made by marketers through mass media platforms or some paid reviewed from public figures. This is because they need more time to make wise decisions to satisfy their respective tastes. In addition, male consumers are less sensitive to the price factor but more sensitive to the quality of goods. Hence, they paid more attention to shopping time than female consumers, who are more concerned about price factors (Yang et al. 2006). Thus, as a result, the choice of male consumers is always changing, as illustrated in their response. That inclined to the neutral scales of the questionnaires, in which $30.3 \%$ of respondents did so. Such as price changes, better taste, quality, promotional offers, due to the environmental issues or other else might be due to their other desired products had been the possibilities impact to their preferences and purchasing decisions and female consumers desired. It was also observed that male consumers also have awareness and a good attitude before investing money for the product.
Table 4 illustrates that the data within the age groups, most of the results showed have expected numbers higher than 5 was the age group of 21-30 years old. Most of its observed numbers have achieved slightly similar or higher numbers than the expected numbers. As the results, three Likert-scaled answers responded by the consumers that showed acceptable data which most respondents stated that they agreed (57.4\%). It followed by neutral responses $(24.6 \%)$, and some of the respondents stated that they strongly agree (18.0\%) with this factor. Either all or some of the questionnaires of the psychological factors had influences on their purchasing decision through marketing activities on mass media platforms as well as words-of-mouth. Meanwhile, for the data within the gender, female respondents stated that they agree (58.2\%), and some stated neutral responses (31.3\%), which also had 17.4 expected numbers higher than five and the 21 observed numbers were higher than the expected numbers. However, the male consumers had 18.5 (agreed) and 8.6 (neutral) expected numbers higher than five but not for observed numbers which 17 (agreed) and 5 (neutral) Likert-scale showed lower than its expected numbers even though the highest total percentages referred to the agreed responses $(51.5 \%)$. Therefore, the acceptable data strongly agree on psychological factors for male respondents with 5.3 expected numbers slightly higher than five and its 11 observed numbers. The data showed in Table 4, and there were differences between all the consumers' responses even though small differences were presented.

Table 3. Crosstabulation between gender and reason changing buying options to buy other types of fruits

\begin{tabular}{|c|c|c|c|c|c|c|c|}
\hline \multirow[t]{2}{*}{ Gender } & & \multicolumn{5}{|c|}{ Reason changing buying options to buy other types of fruits } & \multirow[t]{2}{*}{ Total } \\
\hline & & Price & Promotion & Better quality & Better taste & Ecological issues & \\
\hline \multirow[t]{3}{*}{ Male } & Observed count (n) & 7 & 3 & 10 & 9 & 4 & 33 \\
\hline & Expected count (n) & 5.0 & 3.0 & 9.2 & 13.5 & 2.3 & 33.0 \\
\hline & $\%$ within Gender & $21.2 \%$ & $9.1 \%$ & $30.3 \%$ & $27.3 \%$ & $12.1 \%$ & $100.0 \%$ \\
\hline \multirow[t]{3}{*}{ Female } & Observed count (n) & 8 & 6 & 18 & 32 & 3 & 67 \\
\hline & Expected count (n) & 10.1 & 6.0 & 18.8 & 27.5 & 4.7 & 67.0 \\
\hline & \% within Gender & $11.9 \%$ & $9.0 \%$ & $26.9 \%$ & $47.8 \%$ & $4.5 \%$ & $100.0 \%$ \\
\hline \multirow[t]{3}{*}{ Total } & Observed count (n) & 3 & 6 & 6 & 4 & 1 & 20 \\
\hline & Expected count (n) & 3.0 & 1.8 & 5.6 & 8.2 & 1.4 & 20.0 \\
\hline & \% within Gender & $15.0 \%$ & $30.0 \%$ & $30.0 \%$ & $20.0 \%$ & $5.0 \%$ & $100.0 \%$ \\
\hline
\end{tabular}


Besides, within the working level, three groups of working-level have a higher expected number than 5 . However, for the government groups and still studying respondents, only showed one of each Likert-scaled answer in terms to illustrate that these groups also had observed numbers higher than its expected numbers, which are 12 for government sector group and 17 for 'still studying' respondents. Therefore, these three groups showed acceptable data because the results showed enough differences between each of these variables. These results were more likely had many participants within the students whom most of them still do not have a stable income nor commitments that need to be taken care of. Hence, within the private groups, mostly the respondents stated that they agree $(62.1 \%)$. The government sector group states that they responded neutrally (54.5\%) and 'still studying' respondents state that they agree $(65.4 \%)$ in which psychological factors have influenced consumer buying behaviour in making decisions based on the consumers' working level.
Table 5 illustrates the results of the chi-square tests of psychological factors for each variable in the demographic profile, which had shown a statistically figure on this factor. The table above presents that all the p-values of the Pearson Chi-square test are less than the level value of significance known as alphavalue $=0.05$. It was observed that psychological factors do influenced consumers' purchasing decisions based on age $(p$-values $=0.010)$, gender $(p$-values $=$ 0.005 ) and working-level ( $p$-values $=0.014)$. Thus, there are relationship associations between each of these variables. Therefore, there was a relationship association between consumer demographic profile through these three factors (personal, socio-cultural and psychological) and included with the size effect in the decision-making process behind consumer behaviour that has been made by the consumers while purchasing products.

Table 4. Crosstabulation between demographics profile and psychological factors

\begin{tabular}{|c|c|c|c|c|c|c|}
\hline & & \multicolumn{5}{|c|}{ Psychological Factors } \\
\hline & & S.Disagree & Disagree & Neutral & Agree & S. Agree \\
\hline \multirow{3}{*}{$\begin{array}{l}\text { Age: } \\
21-30 \text { years old }\end{array}$} & Observed count (n) & & 15 & 35 & 11 & \\
\hline & Expected count (n) & & 15.9 & 34.2 & 9.8 & \\
\hline & $\%$ within Age & & $24.6 \%$ & $57.4 \%$ & $18.0 \%$ & \\
\hline \multirow{3}{*}{$\begin{array}{l}\text { Gender: } \\
\text { Male }\end{array}$} & Observed count (n) & & 5 & 17 & 11 & \\
\hline & Expected count (n) & & 8.6 & 18.5 & 5.3 & \\
\hline & $\%$ within Gender & & $15.2 \%$ & $51.5 \%$ & $33.3 \%$ & \\
\hline \multirow{3}{*}{$\begin{array}{l}\text { Gender: } \\
\text { Female }\end{array}$} & Observed count (n) & & 21 & 39 & 5 & \\
\hline & Expected count (n) & & 17.4 & 37.5 & 10.7 & \\
\hline & $\%$ within Gender & & $31.3 \%$ & $58.2 \%$ & $7.5 \%$ & \\
\hline \multirow{3}{*}{$\begin{array}{l}\text { Working Level: } \\
\text { Private }\end{array}$} & Observed count (n) & & 8 & 18 & & \\
\hline & Expected count (n) & & 7.5 & 16.2 & & \\
\hline & \% within Working Level & & $27.6 \%$ & $62.1 \%$ & & \\
\hline \multirow{3}{*}{$\begin{array}{l}\text { Working Level: } \\
\text { Government }\end{array}$} & Observed count (n) & & 12 & 8 & & \\
\hline & Expected count (n) & & 5.7 & 12.3 & & \\
\hline & $\%$ within Working Level & & $54.5 \%$ & $36.4 \%$ & & \\
\hline \multirow{3}{*}{$\begin{array}{l}\text { Working Level: } \\
\text { Still studying }\end{array}$} & Observed count (n) & & 4 & 17 & & \\
\hline & Expected count $(\mathrm{n})$ & & 6.8 & 14.6 & & \\
\hline & $\%$ within Working Level & & $15.4 \%$ & $65.4 \%$ & & \\
\hline
\end{tabular}

Table 5. Psychological factors of chi-squares test

\begin{tabular}{lccc}
\hline & Value & df & Asymptotic Significance (2-sided) \\
\hline Pearson Chi-Square (Age) & $26.329^{\mathrm{a}}$ & 12 & 0.010 \\
Pearson Chi-Square (Gender) & $12.640^{\mathrm{a}}$ & 3 & 0.005 \\
Pearson Chi-Square (Working Level) & $29.371^{\mathrm{a}}$ & 15 & 0.014 \\
\hline
\end{tabular}

a) level value of significance known as, alpha-value $=0.05$ 


\section{Managerial Implications}

The results of this study have implications for pomelo fruit farmers, retailers and market regulatory agencies. Considering consumers' concerns on healthy diet, it is required to develop an appropriate strategy. The strategy should focus on consumer segments, increasing consumer's knowledge on pomelo fruit by maintaining consumer satisfaction. Pomelo are an excellent source of calcium and vitamin C. Therefore, consumers' knowledge about benefit of pomelo is a significant role in making purchase related decisions. This study provides guideline for retailers who are selling pomelo fruits. Besides, this study can be helpful pomelo seller to identify their target consumers based on sociodemographics factors on pomelo fruit purchases.

Despite the significant finding of this study, there are some limitations that must be acknowledge while making interpretation of results. First, we selected some factors to examine the influence on consumer decision. In the future we could incorporate more factors such as advertising, government involvement and distribution while studying consumer decision making. Furthermore, we can expand the validity of the results by increasing number of sample size.

\section{CONCLUSIONS AND RECOMMENDATIONS}

\section{Conclusions}

The main objective of this study is to identify the factors influencing consumers' decisions in purchasing pomelo fruits (Citrus grandis) in Johor, Malaysia. In order to complete the main objective, reliability analysis, the descriptive analysis of frequencies and the crosstabulation analysis with chi-squares test were employed to investigate the perception of consumers based on their behaviour, perceptions, knowledge and any contributing factors. The data from 100 consumers were collected in 10 districts, namely Johor Bahru, Batu Pahat, Kluang, Kulai, Muar, Kota Tinggi, Segamat, Pontian, Tangkak and Mersing. The questionnaires were distributed online through the Google form link due to the Covid-19 pandemic in our country. The findings proved that the personal factors questionnaire was reliable with the chi-squares test even though the output in crosstabulations analysis does not show a strong relationship effect on the consumers' purchasing decisions pomelo fruits. It was also proved that the socio-cultural factors analysis has reliable results compared to the psychological factors questionnaires.

However, in contrast with the output results of using crosstabulations analysis with chi-square tests, the socio-cultural and psychological factors proved a statistically significant figure and the size effect of using both analyses together. Thus, all methods that shown appropriate results have answered all the questions posed in the study's objectives. In conclusion, there was a relationship association between consumer demographic profile through these three factors (personal, socio-cultural and psychological) and included the size effect in the decision-making process behind consumer behaviour made by the consumers while purchasing products.

\section{Recommendations}

Future research could examine the influencing factors such as personal, socio-cultural, psychological factors by using the Theory of planned behaviour to find the intervention model on consumers' decision-making during buying the pomelo fruits. Furthermore, such a study can be combined with the consumers' willingness to pay in examining product attributes' enhancement.

\section{REFERENCES}

Chikkamath M, Atteri BR, Srivastava SK, Roy S. 2012. Factors influencing consumer's behaviour for vegetable purchase. Vegetable Science 39(1): 35-39.

de Run, Almeida LAG, Pereira ET, Tavares FO. 2015. Attitude towards advertising among young adults: a comparative study by ethnicity. International Journal of Business and Society 16(3):397-407.

DOA's Statistic Report. 2019. Booklet Statistik Tanaman 2019. Putrajaya: Unit Geospatial Pertanian dan Statistik.

Glen S. 2014. Cronbach's alpha: Simple definition, use and interpretation. http://statistics howto.com. [5 Jul 2021].

Hulin C, Netemeyer R, Cudeck R. 2001. Can a reliability coefficient be too high?. Journal of Consumer Psychology 10(1):55-58. https://doi. org/10.1207/S15327663JCP1001\&2_05.

Ismail A. 2021. Musim panas jejas hasil limau bali. http://www.bharian.com. [5 Jul 2021].

Ismail A. 2019. Bekalan limau bali jementah kurang 
petani hadkan eskport. http://www.bharian.com. [5 Jul 2021].

Kanchan S, Neeraj. 2018. A study on factors affecting consumers decision to purchase vegetables. International Journal of Current Microbiology and Applied Sciences 7(2):1211-1222. https:// doi.org/10.20546/ijcmas.2018.702.149.

Kardes FR, Cronley MR, Cline TW. 2011. Consumer Behaviour. Edinburgh: Mason $\mathrm{OH}$.

Kotler, Armstrong. 2014. Principle of Marketing. Ed. ke-6. Australia: Pearson Australia Group.

Lautiainen T. 2015. Factors affecting consumers' buying decision in the selection of a coffee brand [tesis]. Finlandia: Saimaa University of Applied Science.

Lind, Marchal, Wathen. 2018. Statistizal Technniques in Business \& Economics. Ed. ke-17. New York: McGraw Hill Education International Edition.

Nathan A, Wong YC. 1987. A Guide to Fruits and Seeds. Singapura: The Centre.

Monsuwe PT, Dellaert CGB, Ruyter K. 2004. What drives customers to shop online? A literature review. International Journal of Service Industry 15(1):102-121. https://doi. org/10.1108/09564230410523358.

Morton JF. 1987. Fruits of Warm Climates. North Carolina: Creative Resource Systems Inc.

Padel S, Foster C. 2005. Exploring the gap between attitudes and behaviour: Understanding why consumers buy or do not buy organic food. British Food Journal 107(8):606-625. https:// doi.org/10.1108/00070700510611002.
Scora RW. 1975. On the history and origin of citrus. Bulletin of Torrey Botanical Club 102: 369-375. https://doi.org/10.2307/2484763.

Solomon et al. 2004. Handbook of Experimental Existential Psychology. Ed. ke-6. New York: Guilford Press.

Solomon MR, Rssell-Bunnett R, Previte J. 2004. Consumer Behaviour A European Perspective. Edinburgh: Pearson Education Limited Prestine Hall.

Solomon MR, Marshall GW, Stuart EW. 2008. Marketing Real People, Real Choices. Ed. ke-5. Edinburgh: Pearson/Prentice Hall.

Uma, Roger. 2016. Research Methods for Business. UK: John Wiley \& Sons Ltd.

Ursachi G, Horodnic IA, Zait A. 2015. How reliable are measurementscales? external factors withindirect influence on reliability estimator. Procedia Economics and Finance 20: 679-686. https:// doi.org/10.1016/S2212-5671(15)00123-9.

UusitaloO. 2001. Consumerperceptions of grocery retail formatsandbrands. InternationalJournalofRetail \& Distribution Management 29(5):214-225. https://doi.org/10.1108/09590550110390995.

Wright R. 2006. Consumer Behaviour. Business \& Economics. Ontario: Thompson Learning

Yang B, Lester D. 2006. Gender differences in e-commerce. Applied Economics 37 ( 18 ): $2077-2089$.https://doi . org/10.1080/00036840500293292. 